\title{
Music and Society in Cyprus: British Colonialism and the Emergence of European Music Traditions
}

\author{
By Anastasia Hasikou*
}

\begin{abstract}
In this paper, I aim to examine a number of aspects of the musical culture of Greek Cypriots during the late nineteenth and early twentieth century, focusing on the emergence of European art music and the consequent impact on the local music traditions. The paper will provide information about musical developments in Cyprus during a period that has not been previously explored, contributing to a better understanding of the subsequent evolution of musical culture on the island. Considering the social stratification of the time, I will examine the impact of European art music on particular Cypriot social classes of the clergy, the peasantry, the traditional urban elite and the newly created middle class. The main sources of the research presented here are products of the island's first urban printing press, which are kept at the Public Information Office and the Archive of the Archbishops of Cyprus.
\end{abstract}

Keywords: Music in Cyprus, Society in Cyprus, Colonialism, European Art Music, Church music, Folk music.

\section{Introduction}

The first years of British colonialism in Cyprus had a significant impact on many aspects of the sociopolitical, economic and cultural life of the island. The arrival of the British signalled for Cyprus the beginning of a long transition from a traditional society to a European capitalist state. Music development, as part of Cypriot culture, was significantly affected by British colonialism. The relation between music and the sociopolitical and economic system under British administration, is a significant aspect in understanding the inherited features of musical culture and subsequently the musical heritage of modern Cyprus.

The local music traditions, church and folk, had been substantially influenced by British colonialism. Transcriptions of church music into European staff notation together with the local manifestations of classical music affected the melodic and rhythmic development of Byzantine chant and neumatic notation in Cyprus as argued in press debates on Greek Cypriot national identity and culture. At the same time, folk music was also shaped within the colonial environment, which inevitably had a significant impact on the folk repertoire. Many social and economic features resulting from the

*Lecturer, Arte Music Academy, Cyprus \& PhD Candidate, Department of Music, City University London, UK. 
colonial conditions were related to the textual content of the period's folk songs.

One of the most noteworthy developments that took place during the early British colonial period was the emergence of the first instances of Cypriots adopting and cultivating Western European musical traditions. Reports in the island's urban press during the first two decades of the 20th century document the appearance in all cities of "philharmonic orchestras" (wind ensembles), as well as of mandolinatas (small orchestras with string instruments) (Kypriakos Fylax, 21 June and 16 October 1908; Salpinx, 16 October 1908). In 1904, Boisselot pianos began to be imported to the island, while in 1907 phonographs and gramophones began to appear in cafés (Salpinx, 7 February 1904; Eleftheria, 13 July 1907) Classical concerts were given in the houses of colonial administrators while British and other foreign musicians living on or travelling to the island offered piano, violin and music theory lessons.

Exploring local newspapers and other documentary sources dating back to the beginning of the colonial period (1878-1914), this chapter examines the impact that this period had on the music of the Greek Cypriot population in Cyprus. It focuses on discussions about church music and the threat of Europeanisation; the textual content of the late nineteenth and early twentieth century folk songs; and the emergence of European classical music among the upper classes. With regard to music in the early British colonial period, this paper demonstrates how 'music culture is usually dependent on social, economic and cultural interactions' (Herbert, 2003, p.150), and how the subsequent formation and understanding of musical culture is a result of these interactions.

\section{Byzantine Music and the European Music Influence}

Church music was often present on the playground of politics and the identity-building process of the Greek Cypriot population. As part of the local music, Byzantine chant was for the local Greek Cypriot nationalist movement ${ }^{1}$, a cultural element that proved the Greekness of the Greek Cypriots. Byzantine music for Cyprus was a powerful symbol for cultural heritage from ancient Greece that it shared with the modern Greek state. Therefore, evidence that Byzantine music was inherited in Cyprus many centuries ago was of great significance during the beginning of the twentieth century. Within this context several newspaper articles argued the point of the existence of a history of Byzantine chant in Cyprus. The following article is an example that defends

\footnotetext{
${ }^{1}$ The Greek Cypriot nationalist movement emerged in the late nineteenth century among the local clergy and part of the traditional urban elite. Its main political aspiration was the union with Greece, which was inspired by the Greek political movement of Megali Idea (Great Idea) that influenced the ethnic Greeks living beyond the borders of the Greek state. According to the dogma of Megali Idea, all the lands of classical and Byzantine Hellenism should be encompassed by the modern Greek state.
} 
the long existence of Byzantine music on the island and the contribution of Cypriots to its transcription and dissemination.

Byzantine Music was spread across Cyprus since earliest times as well, and this is witnessed in the plethora of the existing handwritten music books, in both the older writing and in the more analytical ones of Peter. In any event, it was disseminated by clerics who belonged to the island's holy Monasteries, such as those of Kykkos, Machaeras, etc., who having been sent to Constantinople..., were engaged in learning "music"..., (Salpinx, 4 May 1912, No. 1484).

During the colonial period, the power of the Orthodox Church of Cyprus was significantly degraded. As a result, local discussions about the preservation of Church music under the new political circumstances ensued. For the Orthodox Church of Cyprus (that had been a significant part of the local nationalist movement) the educational system in Cyprus developed into a branch of the mainland Greek educational system, thus preserving Greek cultural characteristics. In this context, Byzantine chant was seen by several local newspapers as national musical patrimony that should be preserved. According to Salpinx, this could be achieved through a 'proper' Greek education:

We warmly applaud the idea expressed in the newspaper Alithia by fellow-citizens to introduce the subject of Byzantine music as a regular lesson in our schools... this subject is highly worthy of studying for its great and precious national importance ...

(4 June 1909, No.1332).

Interplaying with the local nationalist rhetoric, the impact of Western European classical music on the development of Byzantine chant was also much discussed under the debate called mousiko zitima (music question). The greatest concerns expressed in both the Greek and the Greek Cypriot press of the time, concerned the harmonization of the chant, its surrender to polyphonic music, and the replacement of Byzantine tunings with European ones (Romanou, 1996, pp.31-95). Sharing these concerns, the Cypriot teacher of Byzantine chant Stylianos Hourmouzios (also - conveniently - the director and editor of Salpinx) wrote:

The Gymnasium established in Cyprus ... was to become the reason for the disappearance of Pure Byzantine Music from the island because of ignorance or indifference on the part of those responsible. Among the teachers [who came] from Greece ... [was] a teacher capable of teaching both Ecclesiastical and European music. But this teacher ... being ignorant with regard to the pure performance of Byzantine melodies, having been taught by this Athenian musician

\footnotetext{
${ }^{1}$ The term 'Mousiko Zitima' (Music Question) refers to the debate that prevailed in music circles in nineteenth-century Greece regarding the Greekness of Byzantine chant and the tendency to westernize it.
} 
who, in his obsession to harmonize the ecclesiastical melodies turned the Byzantine musical scales upside down two and three times in a vain effort to absorb them into the European ones ...

(Salpinx, 4 May 1912)

The above extract highlights the impact of European music and performance practice on Byzantine chant, resulting in the distortion of the latter. This discussion occurred in the context of a wider concern about the threat of cultural alienation among the Greek Cypriot population due to the spread of European culture by the British colonial power. In music, the controversy centred on the use of Western notation and harmonization as the medium through which Byzantine chant could be transmitted.

Similar criticisms that prove the impact of European classical music were levelled against attempts to transcribe Cypriot folk songs into Western staff notation rather than Byzantine neumes, an example of which is Christos Apostolides's publication of 1910 with the title Cypriot Songs and Dances: 21 Pieces for Singing and Piano, a collection of Cypriot dances and music transcribed in European notation and harmonized for the piano. This publication was heavily criticized in Salpinx by Hourmouzios, whose comments on Apostolides included references to the parallel debate in Greece about the mousiko zitima. As shown in the following extract, Hourmouzios presents many arguments also commonly found in the Greek discussion about the Europeanization of Byzantine music.

Mr Paganas accepts the existence of quarter tones, semitones, $3 / 4$ tones, [whole] tones, $1 / 3$ and $2 / 3$ tones in the Byzantine Scale, whereas you do not accept any other intervals beyond quarter tones as being different from those found in European [music]. It is because of this that writing folk songs in it [i.e. European music] is impossible. (Salpinx, 2 April 1904)

Another main criticism against Apostolides's transcriptions relates to the inclusion of piano accompaniments in the presentation of his songs, which distorted the real melodies. These criticisms were related to the controversies around the Greek expatriate Periklis Aravantinos, and the scholar and chanter Ioannis Sakellarides. In 1902, Sakellarides's use of piano accompaniments for Byzantine chant at the examinations he held at the Byzantine music department of the National Conservatory of Music in Athens was considered a scandal in some Greek quarters (Romanou, 1996, p.37). And Aravantinos was likewise criticized when in 1903 he presented a recital with orchestral instruments at the Royal Theatre as well as a master-class at the Athens Conservatory and a lecture recital at the Parnassus Theatre (ibid., p.163). References to the two Greek examples highlighted the incompatibility of transcribing Byzantine modes using tonal harmony, and the inadequacy of staff notation (compared to neumatic notation) to represent folk and byzantine melodies: '[It is] entirely impossible to write or perform in the European scale folk songs which are of a scale different than the European' (Salpinx, 2 April 1904). 


\section{Colonial Administration and the Music of the Peasantry}

During the first years of the British occupation (1878-1914), Cyprus was characterized by an underdeveloped agricultural economy. Lacking any modern industrial production, its rural peasantry constituted the majority (some $80-90 \%$ ) of the population (Pantelidou \& Hatzikosti, 1992, p.196). An official survey by the British government, 'Survey of Rural Life in Cyprus', identified living conditions as corresponding to those of England during the fifteenth and sixteenth centuries (Surridge, 1930). According to Papapolyviou, 25-30\% of the rural population was living in primitive conditions at the lowest limits of poverty (2003, p.335). The impact of British colonialism on the rural society and economy and the consequent changes in the daily lives of the peasantry, were mirrored in the textual content of the folk songs of the time. ${ }^{1}$

Some of the British government's endeavours to improve the agricultural methods and economic status of the peasant class were not regarded as successful. Colonel Green, who visited Cyprus in 1896, noted 'extraordinary how difficult it [was] to overcome the prejudice of the natives and how loath they seem[ed] to adopt new ideas' (Green, 1914, p.76). Although the Colonial Loans Act had released funds for the development of agriculture on the island, the natives showed great unwillingness to change their traditional agricultural methods. The indigenous population's reluctance to changing the traditional method of ploughing was usually interpreted by the colonialists as a reflection of stupidity or laziness. Commissioner Wauchope (1878) 'singled out idleness as the Cypriots' worst fault, and noted that although they were very poor, they were content if they could find enough to keep body and soul together' (Katsiaounis, 1996, p.134). As Katsiaounis asserts, 'the British failed to see that a fundamental characteristic of this behaviour was the fact that the poor were in control of their own working lives. Contentment in their frugal style of life enhanced the poor's capacity to maintain a considerable degree of their independence and to keep at bay any employer, including the Government' (ibid.).

The fact that the Cypriot peasantry had control of their working lives, based on their traditional agricultural ways, was mirrored in the folk songs of the period that were often inspired by the harvest. Any changes introduced by the British would inevitably have upset their traditional way of life. 'I afxisis tou sitou' (The increase of grain) is a typical song about the seasonal schedule of the peasantry. Such songs were indicative of an emergent sense of ownership of the older ways, and of a corresponding need to keep modernizing employers (including the government) at bay.

[Let me] set out in October

\footnotetext{
${ }^{1}$ There are no recordings of folk songs dating back to the period under examination. The song examples in this paper are derived from more recent references to early British colonialism. Since most of the peasants were illiterate, folk songs were-mainly transmitted orally. Moreover, music printing was in the hands of the urban elite, and it seems they had little interest in preserving Greek-Cypriot folk music before the 1930s.
} 
to fall in love with a sweetheart [seed], ...

And April ripened them [what had been sown]

and May withered them

and then turned them golden...

Happy is the farmer who has sown aplenty.

(Christodoulou \& Ioannides, 1987, p.888) ${ }^{1}$

The British government's reforms in administration and tax collection did not improve the living conditions of the peasant population during the first years of occupation. Abolition of the Ottoman millet system resulted in a gradual increase in the role of the state; in turn, that meant that, in contrast to earlier times on the island, the state had 'the monopoly of claim on taxes which would be paid directly by each individual' (Katsiaounis, 1996, p.72).

Because of the heavy taxation - and, above all, because of the reform in the collection system - the island suffered considerable poverty and degradation up to 1880 . The press of the time confirms this. Thus, Neon Kition published the following: 'The people groan under heavy and unsupportable taxes, are bound hand and foot economically, and as it is therefore impossible to take a step forward, waste away daily, and look in despair at the dark ruinous future awaiting them' (20 October 1882).

The appalling conditions endured by the peasantry are attested in many folk songs about the suffering of the people from British reforms to the taxation system. Characteristic is the song 'To paraponon tou chorikou' (The complaint of the villager), in fifteen-syllable verse in the original:

Barefoot and naked we are sipping the poison of life, and on top we are skinned by the tax collector with his wooden shovel!...

You go to the tax collector to settle your account,

but he wants to collect the old and the new debts and you to count them before him...

(Christodoulou \& Ioannides, 1987, p.348)

Closely related to the arrival of the British in Cyprus was the establishment of the 'property of land' or land tenure (Katsiaounis, 1996, p.99). As another step that aimed to westernize the economy, this reform appeared to be very relevant to the reform of tax collection directly by the state. The 'property of land' reform was for the government a way to force people to increase their cultivation of the land. Mistarkoi (until then live-in or full-time labourers) were mostly affected by the land tenure reform. Those who did not have any property of land became more vulnerable. They became day or week labourers, and were paid in wages instead of bed and board. When they could not find a landowner to employ them, they became unemployed and homeless. This new

\footnotetext{
${ }^{1}$ It is important to note that the lyrics of this song (as well as those of other songs in the same collection) linguistically deviate from the spoken Cypriot Greek dialect of the time (in some cases this may represent the informants' way of speaking).
} 
policy - which directly affected one of the vital stages in the Cypriot calendric cycle, the harvest - was reflected in the music creations of the time.

One example is the song 'To komman tou therou' (Harvesting the crops), which was sung by the mistarkoi and other seasonal reapers. To this day, this song remains one of the most recognized folk songs and is used to accompany a particular dance called the 'playing' of the sickle, which was danced by the mistarkoi. Under the new conditions imposed by the government, the harvest came to be seen by the mistarkoi as a performance with a precise beginning and end; this ritual dancing piece was played during the work. Reapers participated in the dance according to the level of their skill. The best reaper was the chief worker and danced first. This song was also used to accompany the harvest workers as a means to encourage their work efforts and thus increase productivity (Pharmakides, 1938, p.81).

The top worker deserves a pie made of wheat, and his boss [kkiayia] deserves a pie made of barley, and the last harvester deserves a horse with its saddle, to rise early in the morning with only half his denture.

(Michael Avraamides, recording of 1964, in Christodoulou \& Ioannides, 1987, p.894)

\section{The Emergence of European Classical Music}

During the early stages of colonial rule, European music was performed mainly by non-Cypriots at private social evenings in the homes of British dignitaries. Among the musicians were British government officials and a number of musicians who arrived in Cyprus from Smyrna, Istanbul, Italy, Germany, Greece, and Egypt. The first mention of a European music concert in Cyprus appears in Neon Kition one year after the arrival of the British. (Concerts of European music might have taken place in Cyprus before that time too; but there was no press to cover such events prior to 1878). It took place in Larnaca, and the participants consisted of four musicians of different nationalities: Greek, French, Swiss and Italian (3 June 1879). After 1878, several newspapers referred to concerts featuring Western art music organized by British dignitaries with foreign musicians. It seems that the few native Cypriots who attended these concerts were usually people from the traditional elite who were considered to be distinguished personalities and often occupied key administrative positions. In 1900, Kyprios referred to the presentation of 'a nice Italian melodrama' as follows:

Last Saturday evening the fine melodrama Trovatore was performed. His Excellency the High Commissioner, and many other eminent English people, honoured the performance with their presence, but also many of our distinguished people filled the boxes and the parterre. (31 March 1900) 
It was not uncommon for the Greek Cypriot urban press to express appreciation to the British community on behalf of the local people for its contribution to the development of European music on the island, thereby playing a "civilizing, ${ }^{1}$ mission in Cypriot society. It is also notable that many reviews referred to the Cypriots attending these events as eklektoi (the select) or exehouses prosopikotites (distinguished personalities), thus separating them from the lower social class:

A music concert was ... organised by the British people living here and placed under the protection of the Honourable Commander $\mathrm{Mr}$ Michell [sic]. Many and distinguished people attended. The most courteous Mrs Jelajian played on the piano ... selected musical pieces, and the modest K. A. C. Buss performed appropriate songs with Miss Priestly accompanying on the piano. In addition, Miss Corsellis ... performed difficult musical pieces on the violin ... accompanied by the amateur [musician] $\mathrm{Mr}$ Thompson. Other English officers also played ... We express our heartfelt thanks on behalf of the city. (16 April 1904)

The press coverage also witnessed demonstrations of support by British officials, as in this review in Salpinx of a concert by L. Fotiou at Troodos mountain:

Congratulations by the High Commissioner. The concert was crowned with utmost success, and was honoured by the personal presence of $\mathrm{H}$. E. the High Commissioner, the army commander, many distinguished English [people] and other select people.

(10 August 1907)

It is worth mentioning that the classical concert was the first type of musical activity in Cyprus with an attendance fee, and for this reason press advertisements included the price of the ticket, as in this notice in Salpinx of another musical evening with Fotiou at Troodos mountain:

The Greek tenor Mr L. Fotiou ... will perform various melodramatic pieces and selected national songs. Tickets are on sale at 2 shillings for the gentlemen, $1 \frac{1 / 2}{2}$ for the ladies, and 1 for children (27 October 1907).

The European tradition started to permeate the Greek Cypriot middle class when the first European-educated Cypriot musicians appeared and became active in Cypriot society during the first decade of the twentieth century. As the press of the time shows, the first Cypriot musician with an active presence in

\footnotetext{
${ }^{1}$ The dissemination of Western classical music as part of a 'civilizing mission' of the Western world towards a 'backward' east is much debated in ethnomusicology. See Beckles Willson, 2007 \& 2013; Stokes, 2000; O’Connell, 2000; Bolhman, 2000.
} 
Cyprus was Giannakos Dianellos. Having studied violin in Athens and Paris, he returned to Cyprus in 1906, giving concerts in all the towns with great success. His concerts were announced in many newspapers, and reviews were invariably flattering. Salpinx referred to a 'great' (brilliant) concert given by Dianellos, who was accompanied by the well-known pianist Mary Foscolo (9 June 1906). Likewise, Efimeris tou Laou reported: 'We congratulate him, in that with so much hard work he is heading towards creating true glory for himself and for his homeland, Cyprus' (1 July 1906). Along the same lines Eleftheria referred, among other things, to the musician's repertoire, which included works by Beethoven, Bach and Paganini, while it also highlighted the excellent representation of Cypriot society as well as the presence of the British Commissioner and his wife (27 March 1906).

The appearance of Dianellos signalled an intensification of classical musical activity in Cypriot towns. The number of Cypriots studying in Western Europe and returning to Cyprus began to multiply, and with that, came the formation of ensembles with Cypriot participation in the island's larger towns. What is more, as notices of various sorts in the local press indicate, formal instruction in European music began to flourish. The first publications referring to music lessons appeared in 1904. Salpinx advertised 'French and Piano lessons given by Mr and Mrs Dujardin', and 'English and Piano lessons given by Mr and Mrs Gooding' (10 January 1904). By 1907 the first piano lessons seemed to have borne fruit, as the same newspaper announced concerts given by music students (Salpinx, 5 April 1907; and 24 May 1907). In 1908 the first music lessons to be given by Cypriot musicians appeared in the press. Salpinx advertised 'Epistimonika mathimata kleidokymvalou' (Rigorous piano lessons). These lessons were given by T. Rossides, who had studied at the Music School in Brussels, and subsequently returned to Cyprus, where he taught piano, music theory and harmony (9 October 1908).

We can further observe that subsequent to the growth of music teaching on the island, many new Cypriot ensembles, either philharmonic orchestras or mandolinates (mandolin orchestras), were founded, and there was a marked increase in the number of concerts put on by Cypriots. Kypriakos Fylax referred to a concert given by Mandolinata Terpandros in Nicosia as follows: 'A concert with mandolins, guitars and four-stringed instruments in the open air club "Ta Pankypria" under the direction of the distinguished music teacher Mr I. Oikonomakos' (21 June 1908). In addition, Salpinx announced that the Limassol municipality assigned the direction of the philharmonic orchestra of the town to A. Kalligeris (16 October 1908).

The dissemination of European music throughout urban Greek Cypriot society was much assisted by the importation of Western music industry products like musical instruments, phonographs and gramophones. The importation of musical instruments was facilitated by the development of transport systems and, as a consequence, of domestic and international trade. The first report on the import of musical instruments appeared in the press in 1904 and advertised Boisselot pianos: '80 Boisselot pianos in Cyprus. Representatives F. Kolokassides and Son’ (Salpinx, 7 February 1904). This 
was soon followed by an advert for the first piano tuner, Mr Edward J. S. Papasian (Salpinx, 24 April 1904). A few years later, other types of pianos appeared on the Cypriot market. In 1909 the press advertised Otto \& Carl Philipp pianos by the importer Mr M. I. Tziapouras (Salpinx, 15 January 1909), and a little later it advertised W. Hartmann pianos by the importer Mr G. M. I. Efthyvoulou (Salpinx, 18 September 1909). As for string instruments, which enabled the formation of string ensembles in the towns, the press announced in 1908 the first Cypriot maker of European musical instruments: 'Formerly working in Athens for many years... the Cypriot instrument maker $\mathrm{Mr}$ Kyprianos Evangelides, whose instruments have been amazingly disseminated... has decided to settle in Limassol. He undertakes the production of every type of string instrument' (Salpinx, 19 April 1908; and 28 October 1910). Apart from musical instruments, the appearance of the first phonographs and gramophones in cafés and restaurants also made a substantial contribution to the development of European styles of musical entertainment in Cyprus. K. Intzirtzian was one of the first importers of gramophones at the beginning of the twentieth century (Eleftheria, 13 July 1907).

Although musical activity was gradually increasing in Cypriot towns, the standard of performance was still considered by some to be less than satisfactory. Accordingly, there was a mission to create a so-called mousiko aisthima (musical sensibility) among the inhabitants of the towns, modelled explicitly on European norms. ${ }^{1}$ According to the local urban press, acknowledging the value of music and developing a taste for European music would be socially educative for Cypriots and would contribute to a 'modern' and 'civilized' society. The first attempts to build some appreciation of the value of European music emerged during the 1890s. Along this line, Hourmouzios recommended that Cypriot youth should learn classical music:

We urge the youngsters of our town and of all the other towns on the island to rush into learning this fine art [classical music], and they can rest assured that they will never regret this, but to the contrary in most cases, in this life full of mature sorrows and sadness, they will gratefully remember the hour at which they decided to learn this pafsilypon [uplifting; lit. 'one that stops sorrow'] art. (Salpinx, 19 May 1890)

\section{Conclusion}

The early British colonial period had a catalytic effect on changes in Greek Cypriot music culture. Many substantial characteristics of the Greek Cypriot music are inherited from this period, which has considerably channelled subsequent Greek Cypriot cultural development. Social, economic and political aspects that interweaved with local and foreign cultural elements have

\footnotetext{
${ }^{1}$ The 'beneficiary mission' of the dissemination of European music is also discussed by Beckles Willson (2013) in relation to British Palestine, where music was used as a means of 'civilizing' local people. According to Beckles Willson, in the case of Palestine, this mission often served to create social and ethnic separation.
} 
produced the Greek Cypriot cultural mosaic. In the field of music, the crucial influence of the presence of the British is shown in the European classical heritage as well as the Greek Cypriot church and folk musics.

Following the road set in the early colonial period, European classical music continued developing mostly within the urban areas. It is noteworthy that one of the most important aspects of colonial heritage, resulting from the dissemination of European music, was the beginning of the commodification of urban musical activity. At the beginning of the twentieth century, musicmaking began to develop into a separate, independent activity, following the example of the newly introduced European musical tradition. Musical events in Cypriot towns usually required an entrance fee for the public and took place in a specially arranged venue, such as a theatre, concert hall, café or 'association'. Moreover, a mercantile musical culture started taking shape, with teaching, instrument sales and publishing.

These European oriented changes had a drastic impact on the development of the local musics. The colonial character of cultural development left behind a musical heritage that was a combination of local and European elements mostly aiming to feed the European market. The interplay between European elements and Byzantine chant had inevitably affected the development of the latter, resulting in the subsequent formation of the local Byzantine chant. At the same time, folk music had been also affected by European influence as indicated in the European transcriptions of folk songs existing in the Apostolides collection of Cypriot folk music (the only one until 1951). Yet, the impact of colonialism is demonstrated in the textual content of the folk songs (most of it collected and recorded more recently by private initiatives) that reflect many aspects of the sociopolitical and economic scene of the early colonial period.

\section{References}

Apostolides, C., 1910. Cypriot Songs and Dances. 21 Pieces for Singing and Piano. Nicosia: n.p.

Beckles Willson, R., 2007. The East-West Divan Orchestra. British Academy Review, X, pp.15-17.

Beckles Willson, R., 2013. Orientalism and Musical Mission: Palestine and the West. Cambridge and New York: Cambridge University Press.

Bolhman, P.V., 2000. Composing the Cantorate: Westernizing Europe's Other Within. In: G. and D. Hesmondhalgh, eds. Western Music and its Others: Difference, Representation, and Appropriation in Music. Berkeley, LA, London: University of California Press, pp.187-212.

Christodoulou, M., \& Ioannides, C.D., eds., 1987. Kypriaka Dimodi Asmata (Cypriot Folk Songs). Nicosia: Cyprus Research Centre.

Green, A.O., 1914. Cyprus: A Short Account of its History and Present State. Scotland: M.G. Coltart.

Herbert, T., 2003. Social History and Music History. In: M. Clayton, T. Herbert \& R. Middleton, eds. The Cultural Study of Music. A critical Introduction, New York and London: Routledge. 
Katsiaounis, R., 1996. Labour, Society and Politics in Cyprus during the Second Half of the Nineteenth Century. Nicosia: Cyprus Research Centre.

O'Connell, J.M., 2000. Fine Art, Fine Music: Controlling Turkish Taste at the Fine Arts Academy in 1926. Yearbook for Traditional Music, 32, pp.117-142.

Pantelidou A., \& Hatzikosti C., 1992. Istoria tis Kyprou: Mesaioniki kai Neoteri (History of Cyprus: Medieval and Modern). Nicosia: Programme Development Service of the Ministry of Education.

Papapolyviou, P., 2003. Istoria tou Neou Ellinismou (History of New Hellenism). Athens: Ellinika Grammata.

Pharmakides, X.P., 1938. Kypriaki Laografia (Cypriot Folklore). Limassol: Chr. G. Stavrinides.

Romanou, K., 1996. Ethnikis Mousikis Periigisis, 1901-1912. Ellinika Mousika Periodika os Pigi Erevnas tis Istorias tis Neoellinikis Mousikis (Travels in National Music, 1901-1912. Greek Music Journals as a Research Source for the History of Neohellenic Music), vol. I. Athens: Koultoura.

Stokes, M., 2000. East, West and Arabesk. In: G. Born \& D. Hesmondhalgh, eds. Western Music and its Others: Difference, Representation, and Appropriation in Music. Berkeley, LA, London: University of California Press, pp.213-323.

Surridge, B., 1930. A Survey of Rural Life in Cyprus: Based on Reports of Investigators who Visited Villages Throughout the Colony During 1927 and 1928, and Amplified by Statistical and Other Information from the Records of Government. Nicosia: Government Print Office.

\section{Primary Sources: Newspapers}

Neon Kition

3 June 1879

20 October 1882

Salpinx

19 May 1890

10 January 1904

7 February 1904

2 April 1904

16 April 1904

24 April 1904

9 June 1906

5 April 1907

24 May 1907

10 August 1907

27 October 1907

19 April 1908

9 October 1908

16 October 1908

15 January 1909

2 April 1909

4 June 1909

18 September 1909

22 October 1909

28 October 1910

4 May 1912 
Eleftheria

27 March 1906

13 July 1907

Kypriakos Fylax

21 June 1908

Kyprios

31 March 1900

Efimeris tou Laou

1 July 1906 
